\title{
Atlantic lava lakes and hot vents
}

SIR - Submarine lava lakes were first observed on intermediate- to fast-spreading ridges on the Galapagos ridge ${ }^{1}$ and on the East Pacific Rise ${ }^{2}$. They are the result of rapid eruption of very hot and fluid lava. There is a good correlation between high effusion rate, hot fluid lava, lava lakes and high spreading rate. Typical lava lake structures, such as lava pillars and collapsed roofs, have not been reported from slow-spreading ridges, although localized sheet flows accumulating in topographic lows ${ }^{3}$ were described on the AMAR segment of the Mid-Atlantic Ridge at $36^{\circ} 27^{\prime}$ $\mathrm{N}$. We report here the discovery of two extensive lava lakes on the Mid-Atlantic Ridge and their possible implication for the magmatic and hydrothermal circulation beneath slow-spreading ridges.

During the DIVA1 diving cruise (1994) with the submersible Nautile on the MidAtlantic Ridge near the Azores hotspot, two lava lakes were discovered at the central topographic high of the Lucky Strike $\left(37^{\circ} 17.5^{\prime} \mathrm{N}\right)$ and Menez Gwen segments $\left(37^{\circ} 50^{\prime} \mathrm{N}\right)$ (see figure). At Lucky Strike, the lava lake is $300 \mathrm{~m}$ in diameter and lies at the bottom of a 1-km-diameter caldera. Several generations of very fresh lava form superimposed roofs and pillars several metres high. At Menez Gwen the lava lake measures $0.4 \times 1.4 \mathrm{~km}$ and is centred in a $6 \times 2-\mathrm{km}$ axial graben covered with very recent pillow and lobate flows. A 200-mhigh volcano covered with extremely fresh pillows is at the northern end of the graben.

The discovery of lava lakes at the central topographic highs of the segments (see figure) is consistent with the idea that a thick crust and shallow brittle-ductile transition zone characterize the middles of segments, whereas a thin crust and deep brittle-ductile transition zone are present near segment discontinuities ${ }^{4}$. Lucky Strike, the largest $\left(1 \mathrm{~km}^{2}\right)$ hydrothermal vent field on the Mid-Atlantic Ridge, is a ring encircling the lava lake within the caldera. At Menez Gwen the hydrothermal field lies in the graben, near the top of the new volcano with the most recent lava, $1 \mathrm{~km}$ north of the lava lake. The association of a topographic high,

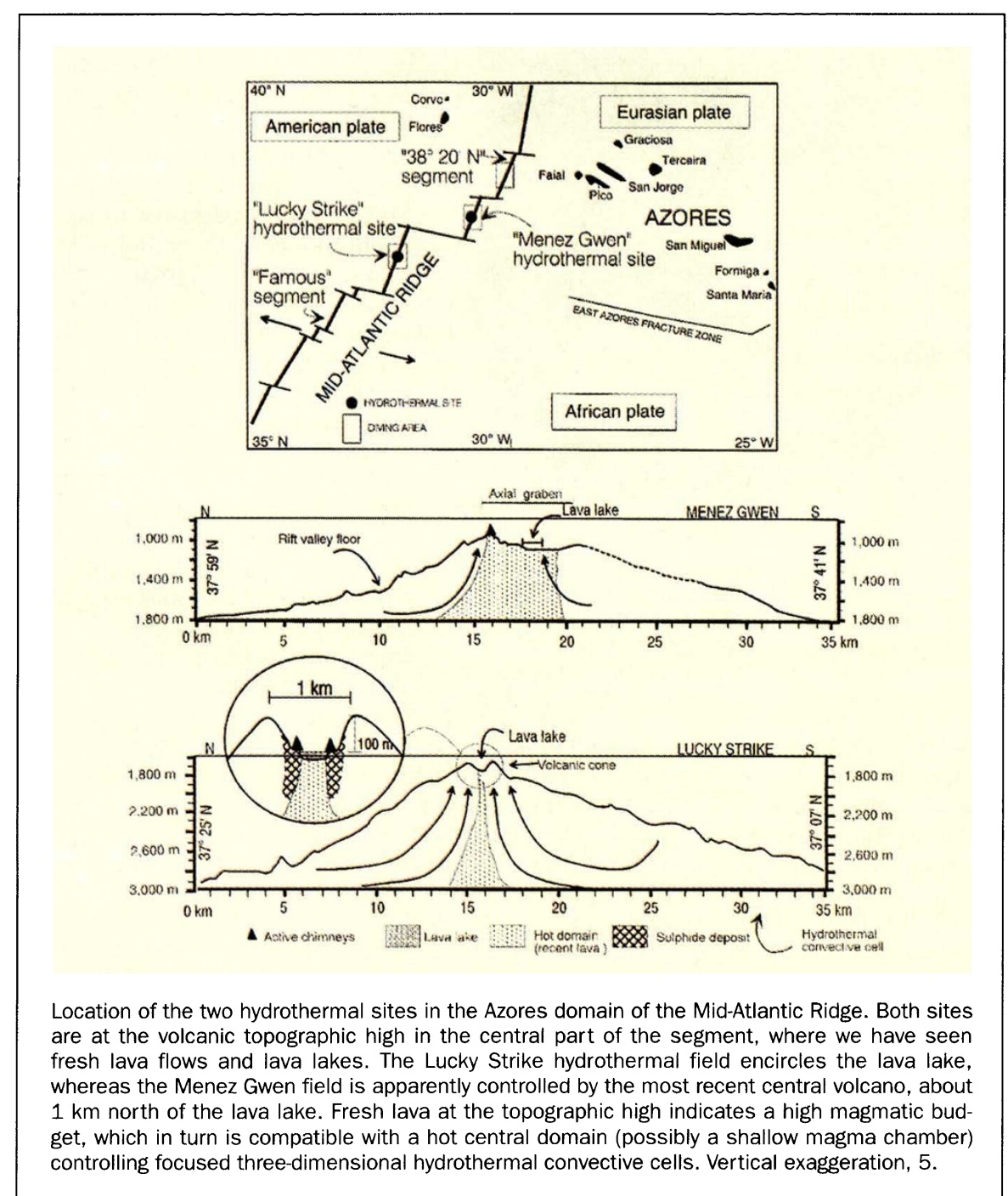

hydrothermal field and lava lake suggests that the rapid localized effusion rate needed to create a lava lake is favoured by close proximity to the top of a shallow axial magma chamber. Thus, we speculate that a shallow magma-lens reflector and seismic low-velocity zone may exist beneath these two sites at the along-axis highs.

Compared with lava lakes on fastspreading ridges, those on slow-spreading ridges are smaller, presumably reflecting a more localized magma chamber. We propose that lava lakes mark on the sea floor the position of the hottest domain and the shallowest part of the magma chamber, suggesting that this heat source has the morphology of a blow torch centred on the topographic high of the segment.

Elsewhere on the Mid-Atlantic Ridge, outside the area of influence of the Azores hotspot, the TAG and Snake Pit hydrothermal deposits (at $26^{\circ}$ and $23^{\circ} \mathrm{N}$, respectively) are not associated with lava lakes. They are, however, located at or near the topographic highs of ridge segments. Thus, as with Lucky Strike and Menez Gwen, their location is controlled by the hottest domain (with high magmatic budget) along the ridge.

The sulphide deposits around the lake can be considered as the trace of the upper part of the hydrothermal convective cells. At Lucky Strike their annular distribution suggests that major upwelling cells are radially distributed, and their exits are controlled by the high-permeability margins of the lava lake and the collapsed caldera. This suggests that, unlike the unstable twodimensional convective systems on fastspreading ridges, slow-spreading ridges with high magmatic budget (near a hotspot) are dominated by more stable three-dimensional convection centred on the volcanic topographic high. This is more compatible with the formation of very large sulphide deposits related to the succession of several hydrothermal episodes at the same location. This is also consistent with the model of two-dimensional passive upwelling under fast-spreading ridges and three-dimensional (diapiric) mantle upwelling under slow-spreading ridges ${ }^{5}$.

Y. Fouquet, H. Ondréas,

J.-L. Charlou, J.-P. Donval,

J. Radford-Knoery

IFREMER, BP 70 ,

29280 Plouzané, France

I. Costa, N. Lourenço

Departamento de Geologia,

Universidade de Lisboa,

1700 Lisboa, Portugal

M. K. Tivey

Woods Hole Oceanographic Institution, Woods Hole, Massachusetts 02543, USA

1. Lonsdale, P. Earth planet. Sci. Lett. 36, 92-110 (1977) 2. Francheteau, J. et al. Nature 281, 209-211 (1979).

3. Atwater, T. Deep Drilling Res. M. Ewing Ser. 2, 33-42 (1979).

4. Sempere, J. C. et al. Mar. geophys. Res. 15, 153-200 (1993).

5. Niu, Y. \& Batiza, R. J. geophys. Res. 98 (B5), 7887-7902 (1993). 